\title{
Value Added Tax (VAT) in Nepal: A Critical Assessment of Its Performance
}

\author{
Kamal Koirala
}

\begin{abstract}
Value Added Tax (VAT) is a recent phenomenon in the arena of tax administration in Nepal. This paper aims to assess critically the performance of VAT in Nepal since its inception to date, focusing basically on three aspects of it, viz, (i) Current scenario of VAT administration (ii) Major issues, and (iii) Urgent corrective actions required. Most of the qualitative and quantitative relevant data have been collected from Economic Survey and office of Inland Revenue Department (IRD). The data comprises of both primary and secondary data
\end{abstract}

Keywords: VAT, enforcement, trade balance, catch-up effect, IRD, tax collection, consumption

\section{Premise}

The term 'Value Added Tax (VAT)' can be defined as a tax levied (on the value created) at each stage in the process of production and distribution of a good or service. These stages can be import, manufacturing, dealers, wholesalers and retailers etc. For example, a large paddy collector from the local farmers pays a percentage on the paddy it sells to a miller. The miller then pays the same percentage (less what the paddy collector paid) on the rice (processed paddy) which it then sells to a hotel. The hotel likewise pays the same percentage (less what the paddy collector and miller paid) on the food it serves to its guest. Proponents of a VAT claim it is transparent as each person or company along the supply chain has an incentive to ensure that every other person or company pays the VAT, and thus reducing the likelihood of tax evasion and avoidance. They also argue that it is more straightforward than other taxes (which it replaces) because there are virtually no exemptions or loopholes. It is based on value added principle.

The tax levied on the value added by the registered taxpayers to their purchase and import is called value added tax (VAT). The basis for VAT is the value addition that takes place at each level in the production and distribution process of goods and services (Khadka, 2001). There are three variants of VAT, namely production-type VAT, income-type VAT, and consumption-type VAT. Production-type VAT is simply calculated on the sum 
of all expenditure on Gross Domestic Product (GDP) net of government wage expenditure (Zee, 1995). Under this variant, capital goods purchased by a firm from other firm are not deductible for the tax base in the year of purchase (Khadka, 1989). Income-type VAT relates with the sum of factor of income payments. Under this system, capital goods used for methods of production are not fully deductible but only a portion relevant to a particular period is allowed to deduct and the remaining portion is carried over for the next period" (Silwal, 2000). Consumption-type VAT basically relates with the domestic consumption irrespective of capital or consumable goods and services.

It is normally implemented under two principles, viz, the origin and destination principles. Under the origin principle, goods and services are taxed at the place where they are produced or rendered whereas destination principle signifies that goods and services are taxed at the place where they are consumed irrespective of its place of production. Imports are exempted and exports are taxed under origin principle while imports are taxed and exports are exempted under destination principle. There are three methods of calculation, viz, addition method, subtraction method, and credit invoice method. Under the addition method, VAT is calculated on the value derived by adding all costs incurred to the factors of production like material, wages, overheads, profits etc. while VAT is calculated by deducting raw materials from the sales under the subtraction method. Under the credit invoice method, tax paid on the purchase of inputs is allowed to deduct from the tax collected from the sale of goods and services. Moreover, some other important aspects of VAT design issues must be addressed. This comprises the numbers of tax rates, the scope of exemptions and zero-rating goods and services, level of exemption threshold, and administrative apparatus.

VAT is the recent innovation in the field of taxation in Nepal. Despite all the constraints and obstructions from the business communities, VAT was introduced in Nepal on 16 November, 1997 with the objectives of increasing revenue mobilization by broadening the tax base, and of instilling neutrality, efficiency, fairness, and transparency in tax administration. It was launched in place of the then four different taxes, namely, Sales Tax, Contract Tax, Entertainment Tax, and Hotel Tax. In Nepal, consumption-type VAT is being implemented in which tax base is dependent upon the following national account:

$$
\text { VAT base }=\text { GDP }- \text { Gw }-\mathrm{I}=\mathrm{Pc}+\mathrm{Gc}+(\mathrm{X}-\mathrm{M}) \text {. }
$$

Where,

GDP $=$ Expenditure on gross domestic production 
$\mathrm{Gw}=$ Government expenditure on wage and salaries

I $=$ Gross investment expenditure

$\mathrm{Pc}=$ Final private consumption

$\mathrm{Gc}=$ Final government nonwage expenditure on goods and services

$\mathrm{X}-\mathrm{M}=$ Trade balance [the values of exported (X) less imported (M) goods and services]

In Nepal, VAT is calculated on invoice credit mechanism in which the registered taxpayer, de jure taxpayer, collects VAT from the consumers, de facto taxpayers, on their taxable supply and offset their input tax paid on their taxable purchases. A transaction within the scope of VAT and on which VAT is imposed is commonly called an input and the VAT collected on it is called output tax (Williams, 1996). Nepal has embraced destination principle that imposes tax on the taxable transaction within the jurisdiction of Nepal. All Imports are taxed and exports are zero-rated in order to lend support for export of domestically produced goods and services through its tax credit and tax refund mechanism. The single standard rate of VAT was set at 10 percent at the outset and subsequently increased to 13 percent since 2005. The government has defined different thresholds for different businesses. The vendors who have taxable transaction of goods worth of Rs. 2 million, of services worth of Rs. 1 million, and of mixed transaction of goods and services worth of Rs. 1 million for the last 12 months are not subject to VAT and they are not required to be registered in VAT.

\section{Performance}

VAT has come of 14 years in Nepal, but it has completed 57 years in the international arena of taxatio as it was firstly introduced in France in 1954. VAT in Nepal has witnessed many ups and downs and twists and turns so far. Despite all the odds, it has been able to prove itself as a strong and healthy backbone of the internal revenue by outstripping custom duties from FY 2002/03 onward and now stands as the largest contributor to the state coffer. At the time of its introduction, there were only 2045 taxpayers converted into VAT from the then sales tax regime, but by the end of FY 2010/11, registration toll has reached to almost 97,664, registering a phenomenal annual average growth of 126.42 percent.

Status of Performance

\begin{tabular}{|l|c|c|c|c|}
\hline Performance Indicators & $\mathbf{1 9 9 7 / 9 8}$ & $\mathbf{2 0 0 1 / 0 2}$ & $\mathbf{2 0 0 6 / 0 7}$ & $\mathbf{2 0 1 0 / 1 1}$ \\
\hline GDP (Rs. in billions) & 300.84 & 459.44 & 727.83 & 1346.82 \\
\hline Consumption(Rs. in billions) & 259.40 & 415.84 & 656.37 & 1257.18 \\
\hline
\end{tabular}




\begin{tabular}{|l|c|c|c|c|}
\hline VAT collection(Rs. in billions) & 8.35 & 12.27 & 26.09 & 61.67 \\
\hline Share of VAT in Total Tax Revenue (\%) & 32.19 & 31.20 & 36.68 & 35.92 \\
\hline Ratio of VAT in Domestic to Import (\%) & $29: 71$ & 25.75 & $37: 63$ & $36: 64$ \\
\hline Ratio of Domestic VAT to GDP (\%) & 0.70 & 0.82 & 1.30 & 1.70 \\
\hline Ratio of VAT to GDP (\%) & 2.78 & 2.67 & 3.58 & 4.58 \\
\hline Standard Rate of VAT (\%) & 10.00 & 10.00 & 13.00 & 13.00 \\
\hline Effective Rate of VAT (\%) & 3.22 & 2.95 & 3.97 & 4.91 \\
\hline Efficiency of VAT (\%) & 27.76 & 26.71 & 27.54 & 35.23 \\
\hline
\end{tabular}

Source: Economic Survey

The VAT comprises 35.92\% of total tax revenue in FY 2010/11 and the pictures during the early years of its inception were also near about the same. The VAT/ GDP growth has been increasing marginally from $2.78 \%$ in FY $1997 / 98$ to $4.58 \%$ in FY 2010/11. The effective rate of VAT was hovering around 3 percent when the standard rate was $10 \%$.It increased to $3.97 \%$ in FY 2006/07 and to 4.91\% in FY 2010/11. The efficiency ratio defined as the ratio of VAT revenue to GDP divided by the standard rate (expressed in percentage) has been widely used as a summary indicator of the performance of the VAT (Ebrill et all, 2001). The marginal efficiency of VAT has been almost stagnant up to FY 2006/07, but start growing in subsequent years and now it is $35.22 \%$ which means only $35.22 \%$ of GDP is under the purview of VAT system. Though VAT collection still relies on import, yet domestic collection has been increasing over the years and reached up to $1.70 \%$ of GDP.

\section{Critical Evaluation}

Improving compliance behavior of taxpayer has been a utopia in Nepal. The registered taxpayers too are not effective and instrumental to the tax generation. By the end of FY 2010/11, around 49\% returns were of credit returns with a mammoth credit amount of Rs. 109 billions and around 18\% are debit returns with meager tax of Rs. 19 billions followed by $33 \%$ zero returns. The credit volume is alarmingly skyrocketing recording almost 5.62 times of debit amount payable to the treasury and 1.73 times of total VAT collection of the year. Another saddening aspect is huge number of non-filers. Around $21.25 \%$ taxpayers are not filing their returns that reflect higher filing risk in VAT administration.

The self-policing and catch-up effect of VAT has turned out to be like an oasis in a far-off desert. Taxpayers are barely interested in observance of law in regards to issuing tax 
invoices in market prices. A sizeable amount of tax is getting fading away by aggressive tax avoidance and evasion. It is further aggravated due to weak enforcement of the law by both the Custom and Inland Revenue Administration at the time of under declaration at custom point, under billing and no billing in the consumer markets. Some criminal-type taxpayers are hell-bent on issuing sham invoices to the fraudulent taxpayers collusively that have resulted in fake input tax and refund claims. Tax refund is no longer able to retain its beauty to the amount it is supposed to; it has rather virtually turned out to be a nightmare in getting back money from treasury to the fraudulent taxpayers by preparing forgery tax invoices and export documents.

Though Inland Revenue Department (IRD) had achieved notable success in reducing VAT dues last year, there is a huge amount of dues yet to be collected in this year. The taxpayers are loath to pay assessed taxes either by lingering the payment date or by following formal means of appeal to the Revenue Tribunal that contribute to the further increase in the amount of dues. IRD has been able to figure out the problems and the vulnerable areas of the system. IRD should buckle down to handle such problems avidly along with the desired professionalism. The newly introduced performance based incentive system (PBIS) has a high bearing on the overall productivity of IRD and it has been effective in motivating and making employees accountable to their performances.

The Government has encouraged using fiscal printers, electronic cash machines to address the issues of tax invoice, but taxpayer are adamant to such initiatives. Tax administration has been launching 'Tax Enforcement Campaign Year' to intensify tax enforcement, but the demonstration effects have been minimal. Given the poor enforcement capability, Nepal's porous borders have been grey areas to breed illegal and fraudulent economic activities. The customers are largely oblivious of VAT system. They are indifferent and do not even bother to ask for bills at the time of their purchases. The malignant taxpayers cash in illegal benefits from the unawareness of the innocent taxpayers to manipulate their transaction.

IRD has been pursuing two-pronged strategies, namely (i) increasing of services delivery with high quality to lure taxpayers towards tax administration and (ii) administering stringent legal actions to the tax dodger. Establishment of Taxpayers Service Offices (TSOs) at the doorstep of the taxpayers will go a long way in focusing on: registration, taxpayer education, tax collection, frequent and friendly visits, market survey and monitoring to enhance the service quality. On the other side, the Inland Revenue Offices (IROs) and Large Taxpayers Office (LTO) have developed an in-built system to detect phony transactions. IRD 
has been lean on taxpayer education and consumer awareness campaign. Apart from this, procedural simplification through application of e-based system, scaling up investment for ICT sophistication, restructuring and reengineering of the organization, decentralization of service delivery, and centralization and specialization of audit and investigation are some lofty initiatives of the IRD.

Some policy changes look urgently desired at the moment. The gargantuan exemption list must be trimmed down to reduce distortion in system and to increase tax base keeping single minimal tax rate. Businessmen want the government to introduce multiple tax rates to make it more progressive and comprehensive. But, wrangling over multiple rates is neither distortion-free nor is it administratively feasible for both taxpayers and tax administration. "An increase in the standard VAT rate may increase informal sector trade and cross-border shopping"(Brys,2011) Any escalation in VAT rate could generate negative spillover effect to the VAT system. Emphasis should be put on the need to maintain the good qualities of VAT (uniformity, a broad base, no cascading, buoyant revenue) by having very few exemption, zero-rating only for export and only one (or at most, two) rate (Tait, 1991). A policy of increasing threshold and introducing annual turnover tax for the non- registered taxpayer could be a viable option for structural reform in VAT. The ever-changing nature and dynamics of service business is also a potential area for VAT administration.

A policy of increasing threshold and introducing annual turnover tax for the nonregistered taxpayer could be a viable option for structural reform in VAT. The ever changing nature and dynamics of service business is also a potential area for VAT administration.

The most challenging aspect of VAT is to address no-billing and under-billing malpractices of the vendors head-on. For this, custom administration should enforce the law to buy all the goods being declared on under-valuation and simultaneously the Inland Revenue administration should also purchase under-invoiced goods and should not spare anybody to bring them under the purview of law. The tax administration and business communities, who were once at loggerhead over the introduction of VAT in Nepal, are now on the same boat to sail through the challenging job. 


\section{REFERENCES}

Brys, B. (2011). Making fundamental tax reform happen: OECD taxation working papers No. 3. Organization for Economic Cooperation and Development (OECD).

Ebrill, L., Keen, M., Bodin, J. P., \& Summers, V. (2001). Understanding the revenue performance of VAT. The Modern VAT. Washington D.C.: International Monetary Fund.

Government of Nepal, Ministry of Finance, (GON) (MOF) (2011). Economic Survey, 2010/11. Kathmandu: MOF.

Khadka, R. B. (2001). Value added tax: The concept, international experiences and its application in Nepal, Value Added Tax Four Years of Implementation. Kathmandu: Inland Revenue Department and Value Added Tax Project.

Khadka, R. B. (1989). VAT in Asia and the Pacific Region. Amsterdam: International Bureau of Fiscal Documentation.

Silwal, N. P. (2000), Value added tax (VAT): A Nepalese experience. Kathmandu: Mrs. Indu Silwal, Sheela Printers.

Tait A. A. (1991). VAT policy issue: Structure, tegressivity, inflation, and export. Value Added Tax: Administration and Policy Issue (edited by Alan A Tait). Occasional paper 88, International Monetary Fund Washington D.C.

Williams, D. (1996). Value added tax: Tax law design and drafting (edited by Victor Thuronyi). Washington D.C.: International Monetary Fund.

Zee, H. H. (1995). Value added tax: Tax policy handbook, edited by Parthasarathi Shome, Washington DC: Fiscal Affairs Department, International Monetary Fund. 